UDK 338.2:330.341 (477)

\title{
ORGANIZATIONAL INNOVATIONS IN THE ACTIVITIES OF CONSTRUCTION COMPANIES IN UKRAINE IN THE TRANSITION TO WORLD STANDARDS OF MANAGEMENT
}

\author{
Redkin Oleksandr ${ }^{1 *}$, Zlepko Oleksandr ${ }^{2}$, Pents Maryna ${ }^{3}$ \\ ${ }^{1}$ Poltava National Technical Yuri Kondratyuk University https://orcid.org/0000-0002-6449-050X \\ ${ }^{2}$ Poltava National Technical Yuri Kondratyuk University https://orcid.org/0000-0002-2811-9877 \\ ${ }^{3}$ Poltava National Technical Yuri Kondratyuk University https://orcid.org/0000-0001-8974-8557 \\ *Corresponding author E-mail: redkinov@ukr.net
}

\begin{abstract}
The scientific bases and practical recommendations for the construction enterprises of Ukraine on the progress of their structure and activity through the implementation of organizational and process innovations proposed in this work are considered. Such innovations are developed on the basis of studying and attracting the best world experience, the latest standards of management of construction investment projects, modern forms and methods of corporate management. Implementation of the proposed innovations will improve the quality, timeliness and efficiency of the construction of individual objects, should improve the structure, functions and performance of enterprises of the domestic construction complex, and ultimately - should increase the competitiveness of the economy and social life in new economic conditions.
\end{abstract}

Keywords: construction and investment projects, improvement of the organizational structure of the enterprise, project management standards.

\section{ОРГАНІЗАЦІЙНІ ІННОВАЦІЇ В ДІЯЛЬНОСТІ БУДІВЕЛЬНИХ КОМПАНІЙ УКРАЇНИ ПРИ ПЕРЕХОДІ НА СВІТОВІ СТАНДАРТИ ГОСПОДАРЮВАННЯ}

\author{
Редкін О.В. ${ }^{1 *}$, Злепко О.С. ${ }^{2}$, Пенц М.В. ${ }^{3}$ \\ 1,2,3 Полтавський національний технічний університет імені Юрія Кондратюка \\ *Адреса для листування E-mail: redkinov@ukr.net
}

\begin{abstract}
Розглянуто наукові основи і практичні рекомендації щодо порядку формування та використання організаційних і процесних нововведень в діяльності будівельних компаній України при переходу на світові стандарти господарювання. Ці нововведення стосуються організаційної структури й основних процесів управління як окремих будівельно-інвестиційних проектів, так і діяльності всієї компанії в цілому. Розглядаючи повний життєвий цикл зведення окремих об'єктів визначено системну модель і перелік основних стандартів професійної діяльності та управління будівельними проектами за умови їх повної та ефективної реалізації «під ключ». В основу цього рішення покладено досвід найкращої практики будівництва передових компаній світу й американські стандарти проектного менеджменту РТВ.К, які при цьому застосовуються. Крім того також визначено, що оскільки потужні будівельні компанії одночасно реалізують «портфель» практично не пов'язаних між собою проектів, то для їх успішного втілення в системі корпоративного менеджменту кожної компанії необхідно створити та якісно використовувати механізми й інструменти мультипроектного управління всім комплексом проектів. Для практичної матеріалізації такої ідеї запропоновано нову, більш досконалу організаційну структуру й основні бізнес-процеси і діяльності будівельного підприємства, які перетворюють його в сучасну будівельно-інвестиційну проектно-орієнтовану та інжиніринговодевелоперську компанію. Втілення запропонованих інновацій сприятиме підвищенню якості, вчасності та ефективності зведення окремих об'єктів, має забезпечити покращення структури, функцій і результатів діяльності підприємств вітчизняного будівельного комплексу, а в кінцевому підсумку - повинне генерувати зростання конкурентоспроможності економіки та суспільного життя в нових умовах господарювання.
\end{abstract}

Ключові слова: будівельні та інвестиційні проекти, вдосконалення організаційної структури підприємства, стандарти управління проектами. 


\section{Introduction}

Today, in the conditions of transition to new standards of management and development of competitive environment in Ukraine, before business, heads of the enterprises and other participants of construction, the main question is search and effective implementation of orders and construction investment projects. The successful experience of leading countries and companies of the world shows that such a task can be effectively implemented on the basis of project and multiproject management standards, and first of all-American standards PMBoK:2017 [1]. They have been successfully used for more than 40 years in the leading construction and investment companies of the world, and since 2017 their sixth version has been operating. Therefore, the attraction of advanced international experience to Ukraine and the formation of its own organizational innovations-standards of project and corporate management for doing business in the construction sector-is an urgent task that has scientific novelty and practical value for both the construction industry and the development of other spheres of the domestic economy.

\section{Recent studies and publications analysis}

In addition to the above-mentioned American project management standards PMBoK:2017, Japanese project management systems P2M, European requirements for the competence of project management specialists IPMA Competence Baseline (ICB) and other standards are also widely used in the world $\left[\begin{array}{ll}1,2 & 2\end{array}\right.$. Such well-known Ukrainian and foreign scientists as: S. Bushuev, V. Voropaev, Yu. Zabrodin, V. Zarenko, N. Ilyin, O. Mikhaylichenko, D. Pinto, M. Razu, V. Shapiro, H. Zachenko made a personal contribution to the development of the theory and practice of project management. [3-8]. But for successful standards application of project management in difficult conditions of Ukraine economy transformation and its transition to the world standards of managing there is a need for further theoretical researches development and development of more perfect practical recommendations on processes management of development and realization "turnkey" construction investment projects taking into account domestic realities of business.

The main purpose of this work is to highlight the theoretical research results and practical tools development for the application of organizational innovations and international experience of project management in the construction enterprises activities of Ukraine while ensuring their competitiveness by switching to international management standards.

\section{Main material and results}

The conducted research enabled to build a system model of construction investment project management (CIP). It is shown in Fig. 1. Considering this model, it is advisable to emphasize that in the project planning (investment) formation documentation, as well as standards for managing the processes of "turnkey" project implementation throughout its life cycle, it is necessary to clearly represent such key parameters (systems, subsystems, processes and elements) of the CIP:

1. The composition of the main participants and stakeholders, their powers and status.

2. Structure, amount, functions and professional skills of the project team.

3 . The structure and duration of the main phases, periods, stages and complexes of the project.

4. The essence of the basic processes of project management and their maximum integration into a single project management process (MP) throughout its life cycle (in terms of implementation "turnkey").

5. The essence of the main functions (standards) of project management, which should be integrated with each other and cover the entire life cycle of the project.

6 . Time and other parameters of project planning that determine the structure and quality of plans, and ultimately-the effectiveness and competitiveness of the project "turnkey".

In the activities of modern construction organizations (enterprises and companies) need to form two types of project management:

1. At the organization of separate objects construction (that is realization "turnkey" of separate construction investment projects), generally, standards of project management are applied, are resulted on Fig. 1 and in table. 1. With a variety of projects, in general, these standards are repeated considering the specific content and conditions of implementation of CIP.

2. On the other hand, a construction organization can simultaneously implement a number of different and unrelated) CIP, which form a portfolio of projects of this organization. For the organization of successful activity of such enterprise (company) the basis of its corporate management should be strategic and multiproject management of portfolio of CIP and the enterprise production program (which, as it is known, is developed for one - two years of the enterprise activity). At the same time, multi-project management should become a new (innovative) basis not only for production, but also for other types of company management.

To effectively address the above two project-oriented transformation areas and progress of Ukrainian construction enterprises in a competitive environment, it must be developed and implemented a number of organizational and process innovations in the system of their future activities. These innovations have been considered.

1. To solve the first of the above-mentioned tasks on the construction organization of individual facilities (implementation of "turnkey" individual projects of CIP) it is recommended in the process of preparation for construction to develop their own (individual) professional activity standards in project management, the recommended list of which is given in table. 1. At the same time, each individual standard (management procedure) should define: 


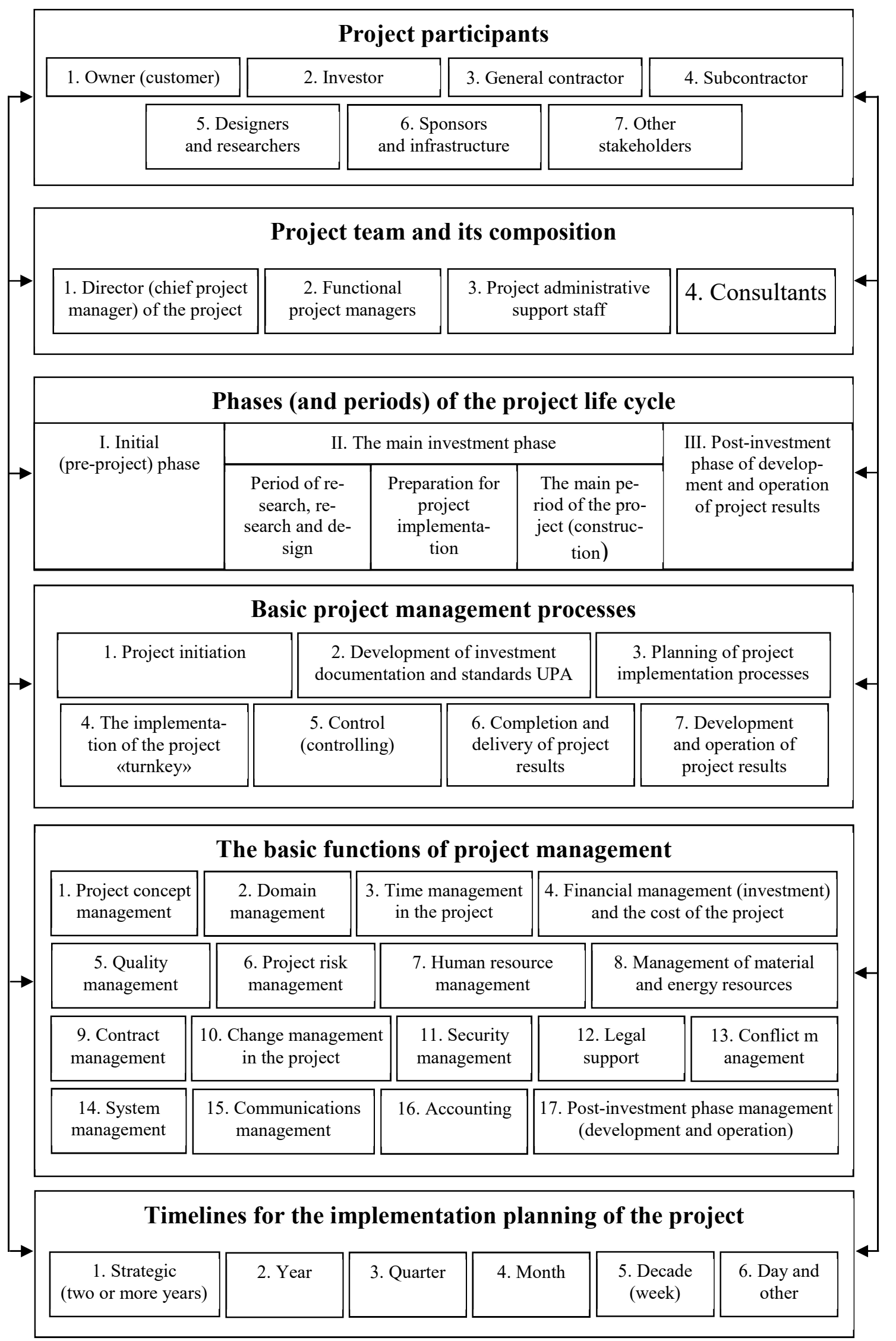

Figure 1 - System model of construction investment project management (investigated on the basis of [8]) 
Table 1 - List of modern professional management standards of construction projects and programs for the enterprises development

\begin{tabular}{|c|c|}
\hline Organizational process & Name of design standards \\
\hline 1 & 2 \\
\hline \multirow{7}{*}{$\begin{array}{l}\text { 1. Provision process inte- } \\
\text { grations professional activi- } \\
\text { ties and project manage- } \\
\text { ment }\end{array}$} & 1.1. Procedure for project charter formation \\
\hline & 1.2. Development of a preliminary scope of work \\
\hline & 1.3. Formation of project management plans \\
\hline & 1.4. Project management guidelines and common standards \\
\hline & 1.5. Order of works monitoring and coordination \\
\hline & 1.6. General requirements for project change management \\
\hline & 1.7. Closing contracts and the project as a whole \\
\hline \multirow{4}{*}{$\begin{array}{l}\text { 2. Organization of project } \\
\text { content management pro- } \\
\text { cesses }\end{array}$} & 2.1. Content planning \\
\hline & 2.2. The definition of a content entity \\
\hline & 2.3. Creating a hierarchical work structure \\
\hline & 2.4. Organization of control over the project content implementation \\
\hline \multirow{6}{*}{$\begin{array}{l}\text { 3. Management calendar } \\
\text { terms of the project imple- } \\
\text { mentation }\end{array}$} & 3.1. Definition of the list of works \\
\hline & 3.2. The definition of interdependence and the structure of the work \\
\hline & 3.3. Identifying and evaluating the resources needed \\
\hline & 3.4. Assessment of labor intensity and duration of work \\
\hline & 3.5. Development and optimization of calendar and resource plans \\
\hline & 3.6. Implementation, operational management and updating of plans \\
\hline \multirow{3}{*}{$\begin{array}{l}\text { 4. Provision cost effective- } \\
\text { ness in the project }\end{array}$} & 4.1. General requirements for determining the cost of work and costs \\
\hline & 4.2. Development of estimates, budget and financial plans \\
\hline & 4.3. Cost management and efficiency \\
\hline \multirow{4}{*}{$\begin{array}{l}\text { 5. Provision } \\
\text { project quality }\end{array}$} & 5.1. General requirements regarding the quality of the project \\
\hline & 5.2. Quality planning of the project and its results \\
\hline & 5.3. Organization of the quality assurance process \\
\hline & 5.4. Organization of quality control \\
\hline \multirow{5}{*}{$\begin{array}{l}\text { 6. Personnel organization } \\
\text { and human resource man- } \\
\text { agement systems in the pro- } \\
\text { ject }\end{array}$} & 6.1. Human resource planning \\
\hline & 6.2. Organizational planning of staff performance standards \\
\hline & 6.3. The order of staff recruitment (project team) \\
\hline & 6.4. The development of the project team \\
\hline & 6.5. Team and human resource management \\
\hline \multirow{5}{*}{$\begin{array}{l}\text { 7. Management } \\
\text { communications project's }\end{array}$} & 7.1. Defining the characteristics and structure of communications \\
\hline & 7.2. Planning the structure and functions of communications \\
\hline & 7.3. Information support \\
\hline & 7.4. The content and procedure of reporting on the project progress and the obtained results \\
\hline & 7.5. Managing project participants \\
\hline \multirow{6}{*}{$\begin{array}{l}\text { 8. Project risk assessment } \\
\text { and management }\end{array}$} & 8.1. Planning of the risk management system \\
\hline & 8.2. The procedure for risk identification \\
\hline & 8.3. Qualitative risk analysis \\
\hline & 8.4. Quantitative risk analysis \\
\hline & 8.5. Risk response planning \\
\hline & 8.6. Project risk monitoring and management \\
\hline \multirow{6}{*}{$\begin{array}{l}\text { 9. Management } \\
\text { deliveries } \\
\text { in the project }\end{array}$} & 9.1. Procurement and supply planning \\
\hline & 9.2. Holding of tenders and conclusion of contracts \\
\hline & 9.3. Collection of information about suppliers and terms of delivery \\
\hline & 9.4. Selection of suppliers and terms of delivery \\
\hline & 9.5. Contract administration \\
\hline & 9.6. Closing of contracts \\
\hline \multirow{9}{*}{$\begin{array}{l}\text { 10. Development and use of } \\
\text { professional activity and } \\
\text { management standards of } \\
\text { specific functions of con- } \\
\text { struction investment pro- } \\
\text { jects and industrial enter- } \\
\text { prises programs } \\
\text { development }\end{array}$} & 10.1. Pre-design work \\
\hline & 10.2.Feasibility study (business planning) \\
\hline & $\begin{array}{l}\text { 10.3. Organization and management of special complexes of substructure, } \\
\text { construction and other works, as well as their participants }\end{array}$ \\
\hline & 10.4. Organizational and technical preparation of construction \\
\hline & 10.5. Safety, health and environmental protection \\
\hline & 10.6. Organization of delivery of completed construction projects \\
\hline & 10.7. The organization and operation of the facilities \\
\hline & 10.8. Development of facilities \\
\hline & 10.9. Else \\
\hline
\end{tabular}


- the content and sequence of works performed according to this standard;- timing and frequency of the management procedure;

- input guidance information and incoming resources;

- mechanisms and tools that are needed to implement this procedure;

- the procedure results;

- system of responsibility distribution among executors of procedure (standard) and on its results as a whole;

- system of procedure efficiency indicators (application of the standard) of management.

The key requirement for the table. 1 the list of standards is that they should be integrated with each other and with the corporate management standards of the construction organization, and cover the entire life cycle of the project in which they are applied.

2. Considering innovative and organizational renewal of structure and corporate management functions of the construction organization which simultaneously realizes a number of various CIP (that is the second group of updating of activity of the domestic enterprises), it is necessary to consider the following remarks and offers.

During the years of Ukraine's independence there was a rapid decentralization of large and hierarchically constructed organizational structures in all sectors of the economy, including construction. At the same time, another economic integration process of small and weak construction enterprises into new organizational structures for Ukraine, such as firms, companies, corporations and holdings, began. In the conditions of competition development such integration is a natural process of mutual adaptation, expansion of economic, production, organizational and investment cooperation, and also own interests protection of each managing subjects. An example of successful cooperation is the creation of a powerful and modern holding company "Kyivgorstroy", which brings together dozens of construction, production, commercial and other enterprises and organizations, thousands of employees along with all their property. Due to this, "Kyivgorstroy" successfully works not only in the city of Kyiv and the nearby region, but also in other regions of Ukraine, qualitatively and in a timely manner performing various types of construction "turnkey" and CMP complexes.

That is, in recent years in the construction industry of Ukraine there are not only decentralization and transformation of large state associations (ministries, factories, trusts, construction enterprises) in new organizational forms of primary (small) construction organizations with different forms of ownership (mainly jointstock and private type), but also began to create modern corporate structures (holdings, companies, financial and industrial groups, corporations, alliances, etc.), which seek to implement in full "turnkey" various construction investment projects with mandatory involvement, effective, quality and timely development of investments. The subjects of investment activity, which include all participants in the construction, in developed countries (and increasingly in Ukraine) can cover several functions in the project implementation process: the developer and the customer; the customer-designer-Builder-user, etc. It should be noted that in the advanced countries and companies the world investment direction of the construction project, which is a set of interrelated stages of one whole investment process in construction projects today requires the implementation of: scoping (or pre-investment) stage of a concept project proof, investment intentions effectiveness, analyzing their alternatives and selecting the most appropriate identify sources of funding, etc.; surveying, design and the necessary research (project engineering); construction and installation works; commissioning, provision of a full range of engineering and development services during operation to ensure the required size and payback period of investments.

For successful use of the recommendations and innovations considered in this paper, in order to improve the performance and results of the modern project-oriented construction and investment enterprise, it is necessary to carry out its organizational modernization and create a new structure in the form of a future powerful holding company with engineering development and projectoriented subsystems and functions. This organizational structure should take into account the results of analysis and programming necessary for business activities of strategic economic zones (SEZ), the implementation of "turnkey" projects and programs, as well as other decisions regarding the development of the enterprise.

Two levels of management should be created in the future company: corporate management center of the whole company (corporate office); management centers of individual strategic economic zones. At the same time, each center will be determined by its functional and managerial characteristics and status: cost center and profit center. In addition, each center will be separated into a legally personified, but economically dependent, division in the form of a subsidiary legal entity, which is part of the entire holding. Should be implemented the rationale and decided that would consider the modern view that holding a legal person (i.e. a person who manages other accountable persons) it is better to create on the basis of a corporate control center, but only on the basis of organizational unit, which brings together executives at the highest level (top management). In accordance with this, the entire management center of the new company should be merged into one legal entity. To manage strategic economic zones, it is advisable to create six legal entities that must manage subsidiaries of their strategic economic zones (SEZ). The Central element of the management system at the SEZ level will be a project-oriented modern construction and development-engineering company, which will organize the activities of other business units within their key functions and specific projects (Fig. 2). In order to build and offer a modern (more perfect) organizational and production structure of a powerful construction company or enterprise (with the number of employees over 400-600 people), it is first necessary to determine its new essence, main features, tasks, business processes, which are characteristic of the leading companies of the world today.

The conducted research enabled to develop a more perfect organizational structure of a new type of construction enterprise for Ukraine a modern project and 
program-oriented construction and investment company. Its activity is based on the world standards of strategic, multi-project, project, corporate and production management, engineering and development. The structure of this company is shown in Fig.2. Its key characteristics and organizational innovations are:

1) integration of the best domestic and foreign experience in the organization and management of construction of various facilities and similar enterprises activities;

2) combination and inclusion in the new organizational structure of this company of modern divisions (for example, such as departments of perspective directions of development of business processes and professional project management and engineering (PMO office) and the like, which work for a single result - ensuring the competitiveness of the construction company and its products - completed construction projects. These divisions should become innovative centers of attraction and use of the best world experience and standards of management of unique projects and programs, and also provide use of engineering and development;

3) that all projects (CIP), main construction sites, auxiliary and other divisions, commercial structures should be transformed into strategic business units (SEZ), which have greater administrative, economic and economic independence.

4) continuous development (in parallel with the Department of professional project management and engineering) of other planning and ensuring the progress departments of promising business activities areas of the company, its development, marketing, corporate service, etc;

5) other innovations.

1. A Guide to the Project Management of Knowledge (2017). Newtown Square: Project Management Institute.

2. P2M. A Guidebook to the Project \& Program Management. For Enterprise Innovation. (2013). Japan; PMAJ.

3. Kendail, G. \& Rollins, S.C. (2008). Advanced Project Portfolio Management and the PMO: Multiplying ROI at Warp Speed. International Institute for Learning, Inc., Boca Raton, Florida.

4. Kerzer, H. \& Wiley, J. (2013). Strategic Planning for Project Management Maturity Model. New York, Sons Inc.

5. Pinto, J.K. (2014). Project Management Handbook. Jossey-Bass Publishers, San Francisco.

6. ДБН А.3.1-5-2016. (2016). Організація будівельного виробництва. Київ : Мінрегіонбуд України.

7. Редкін, О.В., Толкачов, Д.М. (2019). Стратегічне та проектне управління інноваційним розвитком національного господарства, його високотехнологічних наукововиробничих систем і підприсмств. Полтава: ПолтНТУ.

8. Zarenko, V.A. (2006). Project Management. Minsk: ACB Publishing House.
As evidenced by the experience of leading construction and investment companies in the world, the implementation of the domestic enterprises activities proposed by this work innovations and practical recommendations can contribute not only to the involvement in business processes of advanced organization and management standards of construction in Ukraine, but also enables to fully use the latest achievements of science and technology, ensures the growth of economic entities competitiveness. In this case it becomes possible to obtain:

- reducing the complexity and duration of construction (in the implementation of "turnkey" projects) by 12$20 \%$;

- reducing the cost of the entire project by $10-15 \%$ or more;

- increase in times of quality and the project results implementation;

- improvement of technologies, organization forms and working conditions;

- other useful effects.

\section{Conclutions}

The authors believe that the introduction of the proposed innovations and practical recommendations not only improve the quality and modernization of the structure, functions and performance of domestic construction enterprises, but also ensure their competitiveness through the use of international management standards, the embodiment of the best experience, the latest achievements of science, technology and high technologies.

\section{erences}

1. A Guide to the Project Management of Knowledge (2017). Newtown Square: Project Management Institute.

2. P2M. A Guidebook to the Project \& Program Management. For Enterprise Innovation. (2013). Japan; PMAJ.

3. Kendail, G. \& Rollins, S.C. (2008). Advanced Project Portfolio Management and the PMO: Multiplying ROI at Warp Speed. International Institute for Learning, Inc., Boca Raton, Florida.

4. Kerzer, H. \& Wiley, J. (2013). Strategic Planning for Project Management Maturity Model. New York, Sons Inc.

5. Pinto, J.K. (2014). Project Management Handbook. Jossey-Bass Publishers, San Francisco.

6. DBN A.3.1-5-2016. (2016). Organization of construction production. Kyiv: Ministry of Regional Development of Ukraine.

7. Redkin, O.V. \& Tolkachev, D.M. (2019). Strategic and project management of innovative development of the national economy, its high-tech scientific and production systems and enterprises. Poltava: PoltNTU.

8. Zarenko, V.A. (2006). Project Management. Minsk: ACB Publishing House. 